\title{
FRAMEWORK: ACTIVITY-BASED COSTING IN SERVICES
}

FRAMEWORK: MÉTODO ABC DE CUSTOS EM SERVIÇOS

Recebido 25/07/2013 Aceito 05/04/2014

Nara Medianeira Stefano ${ }^{1}$

Maria do Carmo Duarte Freitas ${ }^{2}$

\begin{abstract}
Organizations have a constant need to be prepared to continue competing, which shows the search for alternatives for their stay in the market. It has become a common goal in today's business environment, to improve efficiency and restructure organization, turning it effective. In this context, information about costs has become increasingly important to support and justify the process of decision-making. This article is aimed at structuring a bibliography portfolio to treat the application of the $A B C$ method in service and contribute to discussions within the scientific community. The methodology followed a threestage procedure: Planning, execution and Synthesis. International databases were used to collect information (ISI Web of Knowledge and Scopus). As a result, we obtained a bibliography portfolio of 21 articles (with scientific recognition) dealing with the proposed theme.
\end{abstract}

Keywords: Bibliometrics; Bibliography portfolio; Costs; Services.

1 Possui graduação em Economia pela Universidade Federal de Santa Maria - UFSM, mestrado em Engenharia de Produção pela Universidade Federal de Santa Maria - UFSM, doutorado em Engenharia da Produção pela Universidade Federal de Santa Catarina UFSC. Atualmente é pós-doutoranda na Universidade Federal do Paraná - UFPR. Florianópolis, Santa Catarina, Brasil. E-mail: stefano.nara@ gmail.com.

2 Possui graduação em Engenharia Civil pela Universidade de Fortaleza - UNIFOR, mestrado e doutorado em Engenharia da Produção pela Universidade Federal de Santa Catarina - UFSC. Atualmente é professora na Universidade Federal do Paraná - UFPR. Curitiba, Paraná, Brasil. E-mail: carmemk2@gmail.com. 


\section{RESUMO}

As organizações têm uma necessidade constante de estarem preparadas para continuar a competir, o que mostra a busca de alternativas para a sua permanência no mercado. No ambiente empresarial de hoje, tornou-se um objetivo comum reestruturar e melhorar a sua eficiência, transformando-o em eficaz. Neste contexto, a informação sobre os custos torna-se cada vez mais importante para apoiar e justificar o processo de tomada de decisão. Este artigo tem o objetivo de estruturar de um portfólio bibliográfico de artigos para tratar da aplicação do método $A B C$ em serviço e, desta forma contribuir para as discussões no meio da comunidade científica. A metodologia seguiu um processo de três fases: Planejamento, Execução e Síntese. Bases de dados internacionais foram utilizadas para a coleta das informações (ISI Web of Knowledge e Scopus). Como resultado, obteve-se um portfólio bibliográfico de 21 artigos (com reconhecimento científico) que tratam do tema proposto.

Palavras-chave: Bibliometria; portfólio bibliográfico; custos; serviço.

\section{INTRODUCTION}

The $A B C$ method has the fundamental characteristic to seek to reduce distortions caused by arbitrary allotment of indirect costs acquired in traditional systems. Indeed, $A B C$ is one of the methods made and published about the application of this method (GUNASEKARAN et al., 1999; HUSSAIN and GUNASEKARAN, 2001; COTTON et al., 2003; KELLERMANNS and ISLAM, 2004; KALLUNKI and SILVOLA, 2008; DUH et al., 2009; DUGEL and BIANCHINI, 2011; LUTILSKY and DRAGIJA, 2012; JÄNKÄLÄ and SILVOLA, 2012; SCHULZE et al., 2012).

With economic development and increased competitiveness, the services sector began to look for new concepts in management, so it could monitor the market, increasingly demanding (MAUD and PAMPLONA, 2003). Despite the different characteristics in relation to the manufacturing (GUNASEKARAN and SARHADI, 1998) sector, it has been seeking and adapting concepts used successfully in the cost area.

The current economic climate meant that the service organizations feel the need to know, control and manage their costs effectively. Hence, the importance of investing in programs aimed at reducing production costs. Expenses that with some care, could often be easily prevented or at least reduced, often turn out to link the final cost of products and/or services. In general, the cost controls in service organizations have some points in common with those practiced in the industry. Such issues are production order (LINS and SILVA, 2005), contribution margin and balance point, and can be applied in many service organizations.

Therefore, within this context, the aim of this article is to structure a bibliography portfolio to check the use of the $A B C$ method in service and contribute to discussions within the scientific community. The methodological approach used was a literature review based on bibliometrics (FØRSUNDA and SARAFOGLOU, 2005; Tsai, 2011; Tan et al., 2010; TSAY and SHU, 2011; GUMPENBERGER et al., 2012; VAN RAAN, 2012) and qualitative and quantitative analysis of the articles. The databases chosen to select the publications was portal ISI Web of Knowledge e Scopus for being comprehensive and multidisciplinary (and can be accessed via the Portal CAPES3 Brazil), and period of searches comprises 1990-2011. The methodology followed a three-stage procedure: planning, execution and reporting. Process ProKnow-C (Knowledge Process Development - Constructivist) was also used in the stage of execution.

Besides this introduction, the paper presents: (ii) research methodology, (iii) results; (iv) Conclusions; and, finally, (v) references used.

\footnotetext{
${ }^{3}$ www.periodicos.capes.gov.br.
} 


\section{RESEARCH METHODOLOGY}

This section discusses choice procedures and methodology description.

\subsection{Methodology Choice}

An analytical review is necessary to systematically assess the contribution of a particular literature topic. Generally, the review process consists of three parts: data collection, data analysis and data synthesis. The scientific rigor in the conduct of each of these steps is critical to an analysis of its quality. Data collection can be done in different ways. As an example, using existing knowledge in the literature to select articles and search various databases using keywords.

Once items are selected for review, data analysis can proceed in different ways, depending on the objectives of the revision (CROSSAN and APAYDIN, 2010). A review to consolidate the results of several empirical studies may depend on either qualitative or quantitative analysis of the results. Data synthesis is the main product of the research as it produces new knowledge based on complete data collection.

This research is descriptive (RICHARDSON, 2008). It is descriptive because it seeks to describe the characteristics of scientific publications of this portfolio and its references, in case, the application of $A B C$ method of costs in services.

\subsection{Methodology Description}

For this paper, a three-stage procedure was followed: Planning, Implementation and Synthesis (Figure 1). During the Planning phase, the research objectives were defined and the sources of data were identified. The second stage, Implementation, consists of two sub-steps: identifying the initial selection criteria (time, databases and keywords) and using the ProKnow-C (Knowledge Development Process-Constructivist).

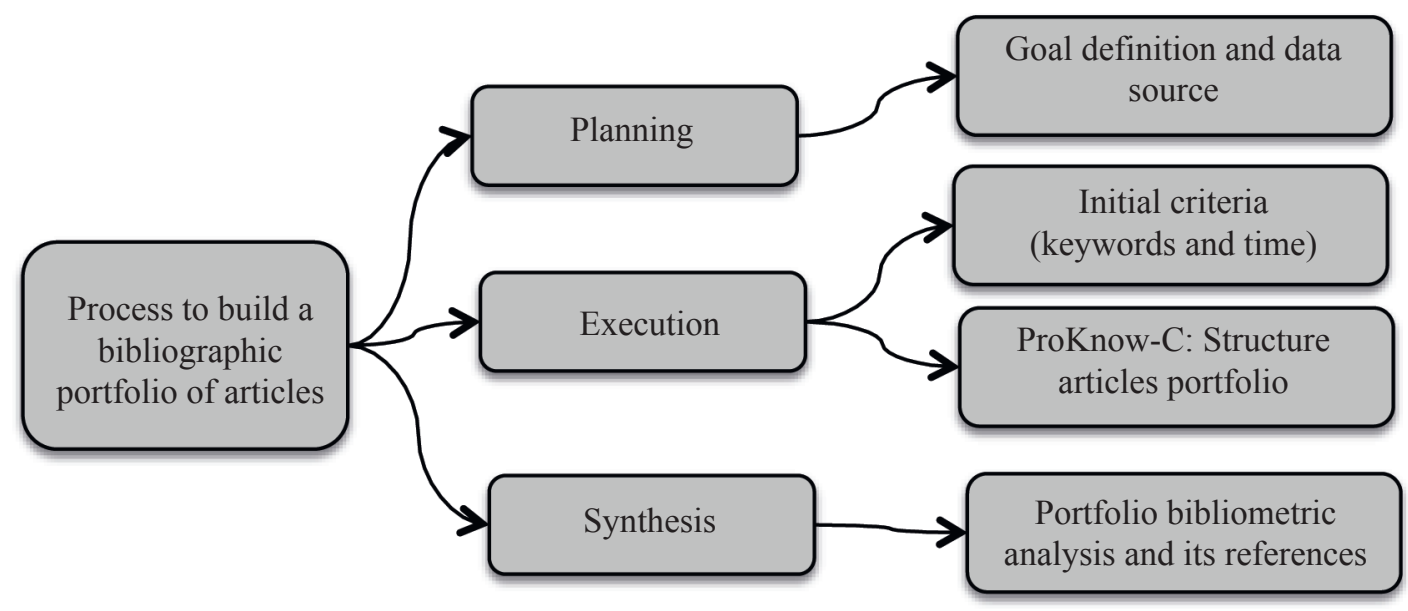

Figure 1: Proposed structure for the paper

Source: Author

ProKnow-C is proposed by Ensslin et al. (2010) to build knowledge based on a researcher's interests and boundaries, according to the constructivist view. This instrument (Bortoluzzi et al., 2011), provides the steps to be followed for the construction of a Bibliographic Portfolio selection representing the topic that you want to search. This phase is divided into two steps:

(1) Selection of gross articles stock; 
(2) Filtering the stock items, which is secreted into five sub-steps:

c) Gross articles stock filter regarding redundancy;

d) Non-recurrent gross articles stock filter regarding title alignment;

e) Non-recurrent gross articles stock filter with title alignment regarding scientific recognition;

f) Article reanalysis process that do not have science recognition;

g) Filter regarding complete article alignment.

The third and last step concerns the Synthesis that is the portfolio bibliometric analysis and its references. It was chosen to be limited only to journals as data sources because they can be considered validated knowledge and are likely to have greater impact. Articles published in conferences and seminars were not considered, as well as books, dissertations and theses. ISI "Web of Knowledge" and Scopus databases were chosen because the databases are comprehensive and multidisciplinary. Interesting, the characteristic of these bases is that they have the scores of citations of articles, and this allows a screening of a series of articles based on this criterion. The number of times an article is cited in Google Scholar was considered, for in ISI Web of Knowledge and Scopus only the journals or databases within it counted and not all the bases where this article is. The time used for the search was 1990 to 2011.

\section{ACTIVITY-BASED COSTING}

The $A B C$ approach treats the client as the object of cost analysis, in parallel with the analysis of ownership costs for suppliers (NIRAJ et al., 2001; NARAYANAN and SARKAR, 2002; ANDERSON, 2005; SALEM-MHAMDIA and GHADHAB, 2012). The emphasis is on getting a better understanding of the behavior of indirect costs. The $A B C$ system is designed and implemented on the premise that products consume activities, activities consume resources and resources consume costs. Thus, the terms activities, drivers and resources are important for understanding $A B C$.

$A B C$ was born in North America. This should not come as a surprise to anyone as a cost analysis system is a reflection of its economic environment. Many, if not most, North American businesses were using, since the post WWII era, up until the late seventies, a simplistic and very economical approach for product costing that allocated overhead most of the time on the basis of direct labor costs (LEBAS, 1999).

An activity is the result of the combination of technological and financial material and human resources used to produce goods and services. The cost driver is the way in which costs are assigned to activities, they form the basis of $A B C$, and seek to trace the origin of the cost and establish a relationship of cause/effect. Resources or inputs are necessary expenses, arising from regular operations of the organization, such as depreciation, water, wages and electricity. The amount of each driver that is associated with the activity that you want to cover is called a factor of resource consumption.

The activity-based costing literature defines an activity as any discrete task that an organization undertakes to make or deliver a product or service (SUSSKIND, 2010; BÜYÜKÖZKAN et al., 2011; BÜYÜKÖZKAN and ÇIFÇI, 2012; GRISSEMANN and STOKBURGER-SAUER, 2012; GUNASEKARAN and SPALANZANI, 2012; CALABRESE, 2012), and a cost driver as a factor that causes or drives an activity's costs (ITNNER, 1999).

The method consists of several variables that must be accuracy defined for your application. 


\section{RESULTS}

Section 3 of the work presents the analysis relating to research data.

\subsection{Portfolio Building}

The phase selection of gross articles stock was completed with 247 articles found (Figure 2), according to the search criteria provided.

- Usage of the following keywords: "activity-based costing" AND services;

- Search on "Web of Knowledge and Scopus: using filters article title, Abstract, Keyword:

$\checkmark$ Total search: 247 articles;

$\checkmark$ Samplings saved in Software Endnote;

$\checkmark$ On the Endnote: find duplicates -54 duplicates;

$\square$ Affinity analysis: title and keywords: 193 (Eliminated: 84 articles);

$\checkmark$ Total articles to perform keywords and title analysis and abstract: 109 (Eliminated: 75 articles);

$\checkmark$ Content analysis: 34 articles - Eliminated: 13 papers, six of these are paid with no free access and 7 had no specific focus, or were just about services;

$\square$ Final portfolio: 21 articles;

$\square$ Bibliometric analysis

For the next step, article stock filtration was performed, then stored in the management software bibliographic references EndNote version Web. This second stage was divided into three separation stages as to: (i) title alignment (ii) scientific recognition (citation number) of the articles and abstracts reading and, (iii) complete reading of the articles. Figure 2 shows a summary of the steps.

The review stage was performed with 34 articles, with proven scientific recognition, from these: 13 were eliminated (six bases were paid without access via portal Capes, and 7 had no specific focus of $A B C$ method of costs in services, because they addressed only services or only $A B C$ ). At the end, there were 21 remaining articles, which build the portfolio on the topic in question (Table 1).

Table 1: Bibliographic portfolio of articles

\begin{tabular}{|c|c|c|c|}
\hline Title & Authors & Journal & Years \\
\hline $\begin{array}{l}\text { A generalised cost-estimation model } \\
\text { for job shop }\end{array}$ & Aderoba, A. & $\begin{array}{l}\text { International Journal of } \\
\text { Production Economics }\end{array}$ & 1997 \\
\hline $\begin{array}{l}\text { Application of activity-based costing } \\
\text { to a land transportation company: a } \\
\text { case study }\end{array}$ & $\begin{array}{l}\text { Baykasoğlu, A.; Kaplanoğlu, } \\
\text { V. }\end{array}$ & $\begin{array}{l}\text { International Journal of } \\
\text { Production Economics }\end{array}$ & 2008 \\
\hline $\begin{array}{l}\text { Applying activity based costing model } \\
\text { on cost accounting of provider of uni- } \\
\text { versal postal services in developing } \\
\text { countries }\end{array}$ & $\begin{array}{l}\text { Blagojević, M.; Marković, } \\
\text { D.; Kujačić, M.; Dobrodolac, } \\
\text { M. }\end{array}$ & $\begin{array}{l}\text { African Journal of Busi- } \\
\text { ness Management }\end{array}$ & 2010 \\
\hline $\begin{array}{l}\text { Improving hospital cost accounting } \\
\text { with activity-based costing }\end{array}$ & Chan, Y. C. & $\begin{array}{l}\text { Health Care Management } \\
\text { Review }\end{array}$ & 1993 \\
\hline $\begin{array}{l}\text { Costing police services: the politiciza- } \\
\text { tion of accounting }\end{array}$ & Collier, P. M. & $\begin{array}{l}\text { Critical Perspectives on } \\
\text { Accounting }\end{array}$ & 2006 \\
\hline
\end{tabular}




\begin{tabular}{|c|c|c|c|}
\hline Title & Authors & Journal & Years \\
\hline $\begin{array}{l}\text { Customer profitability analysis with } \\
\text { time-driven activity-based costing: a } \\
\text { case study in a hotel }\end{array}$ & Dalci, I.; Tanis, V.; Kosan, L. & $\begin{array}{l}\text { International Journal of } \\
\text { Contemporary Hospitality } \\
\text { Management }\end{array}$ & 2010 \\
\hline $\begin{array}{l}\text { Health-care financial management in } \\
\text { a changing environment }\end{array}$ & $\begin{array}{l}\text { Devine, K.; O'clock, P.; Ly- } \\
\text { ons, D. }\end{array}$ & $\begin{array}{l}\text { Journal of Business Re- } \\
\text { search }\end{array}$ & 2000 \\
\hline $\begin{array}{l}\text { Development of an activity-based } \\
\text { costing model to evaluate physician } \\
\text { office practice profitability }\end{array}$ & Dugel, P. U.; Tong, K. B. & Ophthalmology & 2011 \\
\hline $\begin{array}{l}\text { A new method of accurately identi- } \\
\text { fying costs of individual patients in } \\
\text { intensive care: the initial results }\end{array}$ & $\begin{array}{l}\text { Edbrooke, D. L. Stevens, V. } \\
\text { G.; Hibbert, C. L.; }\end{array}$ & Intensive Care Medicine & 1997 \\
\hline $\begin{array}{l}\text { Activity-based costing in user services } \\
\text { of an academic library }\end{array}$ & Ellis-Newman, J. & $\begin{array}{l}\text { The Journal of Academic } \\
\text { Librarianship }\end{array}$ & 2003 \\
\hline $\begin{array}{l}\text { The cost of library services: Activi- } \\
\text { ty-based costing in an Australian aca- } \\
\text { demic library }\end{array}$ & $\begin{array}{l}\text { Ellis-Newman, J.; Robinson, } \\
\text { P. }\end{array}$ & Library Trends & 1998 \\
\hline $\begin{array}{l}\text { Providing professional mammogra- } \\
\text { phy services: financial analysis }\end{array}$ & $\begin{array}{l}\text { Enzmann, D. R.; Anglada, P. } \\
\text { M.; Haviley, C.; Venta, L. A. }\end{array}$ & Radiology & 2001 \\
\hline $\begin{array}{l}\text { Building an activity-based costing } \\
\text { hospital model using quality function } \\
\text { deployment and benchmarking }\end{array}$ & $\begin{array}{l}\text { González, M. E.; Quesada, } \\
\text { G.; Mack, R.; Urritia, I. }\end{array}$ & $\begin{array}{l}\text { Benchmarking: An Inter- } \\
\text { national Journal }\end{array}$ & 2005 \\
\hline $\begin{array}{l}\text { Management accounting systems in } \\
\text { Finnish service firms }\end{array}$ & $\begin{array}{l}\text { Hussain, M. M.; Gunaseka- } \\
\text { ran, A.; Laitinen, E. K. }\end{array}$ & Technovation & 1998 \\
\hline $\begin{array}{l}\text { The application of activity-based cost- } \\
\text { ing in the United Kingdom's largest } \\
\text { financial institutions }\end{array}$ & Innes, J.; Mitchell, F. & $\begin{array}{l}\text { The Service Industries } \\
\text { Journal }\end{array}$ & 1997 \\
\hline $\begin{array}{l}\text { Time-driven activity-based costing for } \\
\text { inter-library services: a case study in } \\
\text { a university }\end{array}$ & $\begin{array}{l}\text { Pernot, E.; Roodhooft, F.; } \\
\text { Van den Abbeele, A. }\end{array}$ & $\begin{array}{l}\text { The Journal of Academic } \\
\text { Librarianship }\end{array}$ & 2007 \\
\hline $\begin{array}{l}\text { Activity-based costs of blood trans- } \\
\text { fusions in surgical patients at four } \\
\text { hospitals }\end{array}$ & $\begin{array}{l}\text { Shander, A.; Hofmann, A.; } \\
\text { Ozawa, S.; Theusinger, O. } \\
\text { M.; Gombotz, H.; Spahn, } \\
\text { D. R. }\end{array}$ & Transfusion & 2010 \\
\hline $\begin{array}{l}\text { Costs and effects in lumbar spinal } \\
\text { fusion: a follow-up study in } 136 \text { con- } \\
\text { secutive patients with chronic low } \\
\text { back pain }\end{array}$ & $\begin{array}{l}\text { Soegaard, R.; Christensen, } \\
\text { F. B.; Christiansen, T.; } \\
\text { Bünger, C. }\end{array}$ & European Spine Journal & 2007 \\
\hline $\begin{array}{l}\text { Logistic costs case study: an ABC ap- } \\
\text { proach }\end{array}$ & $\begin{array}{l}\text { Themido, I.; Arantes, A.; } \\
\text { Fernandes C;. Guedes A P. }\end{array}$ & $\begin{array}{l}\text { Journal of the Operational } \\
\text { Research Society }\end{array}$ & 2000 \\
\hline $\begin{array}{l}\text { Activity-based management and tra- } \\
\text { ditional costing in tourist enterprises } \\
\text { (a hotel implementation model) }\end{array}$ & Vazakidis, A.; Karagiannis, I. & Operational Research & 2011 \\
\hline $\begin{array}{l}\text { Application of activity-based costing } \\
\text { (ABC) for a Peruvian NGO healthcare } \\
\text { provider }\end{array}$ & $\begin{array}{l}\text { Waters, H.; Abdallah, H.; } \\
\text { Santillán, D. }\end{array}$ & $\begin{array}{l}\text { International Journal of } \\
\text { Health Planning and Man- } \\
\text { agement }\end{array}$ & 2001 \\
\hline
\end{tabular}

Source: Author

In the next subsection, the results of the portfolio profile will be presented, constructed as: recognition of scientific articles, journals that most stand out; featured authors and keywords used. 


\subsection{Bibliographic portfolio of articles Analysis}

Performed the entire procedure to build a representative bibliographic portfolio to discuss the use of the $A B C$ method in services, the next step was to treat these articles through bibliometric analysis.

Bibliometrics (DORBAN and VANDEVENNE, 1992; MACIAS-CHAPULA, 1998; MUKHERJEE, 2009; TASCA et al., 2010) is a technique that allows situating the research through various indicators and relationships. As the indicators can be used, the number of citations, co-authorship, number of patents, as well as maps can be made of scientific fields and countries. Table 2 shows the scientific recognition indicator held in the article portfolio.

Table 2: Number of citations (scientific recognition) of the bibliographic portfolio

\begin{tabular}{|c|c|}
\hline Title & $\begin{array}{l}\text { Number of } \\
\text { citation }\end{array}$ \\
\hline Improving hospital cost accounting with activity-based costing & 119 \\
\hline $\begin{array}{l}\text { A new method of accurately identifying costs of individual patients in intensive care: the } \\
\text { initial results }\end{array}$ & 75 \\
\hline Activity-based costs of blood transfusions in surgical patients at four hospitals & 46 \\
\hline $\begin{array}{l}\text { The application of activity-based costing in the United Kingdom's largest financial institu- } \\
\text { tions }\end{array}$ & 44 \\
\hline Logistic costs case study - an ABC approach & 35 \\
\hline A generalised cost-estimation model for job shop & 33 \\
\hline Management accounting systems in Finnish service firms & 29 \\
\hline Application of activity-based costing to a land transportation company: a case study & 27 \\
\hline Providing professional mammography services: financial analysis & 27 \\
\hline The cost of library services: Activity-based costing in an Australian academic library & 23 \\
\hline Costing police services: the politicization of accounting & 21 \\
\hline Application of activity-based costing (ABC) for a Peruvian NGO healthcare provider & 21 \\
\hline $\begin{array}{l}\text { Building an activity-based costing hospital model using quality function deployment and } \\
\text { benchmarking }\end{array}$ & 18 \\
\hline Time-driven activity-based costing for inter-library services: a case study in a university & 19 \\
\hline Activity-based costing in user services of an academic library & 18 \\
\hline Health-care financial management in a changing environment & 16 \\
\hline $\begin{array}{l}\text { Costs and effects in lumbar spinal fusion: a follow-up study in } 136 \text { consecutive patients } \\
\text { with chronic low back pain }\end{array}$ & 15 \\
\hline $\begin{array}{l}\text { Customer profitability analysis with time-driven activity-based costing: a case study in a } \\
\text { hotel }\end{array}$ & 5 \\
\hline $\begin{array}{l}\text { Development of an activity-based costing model to evaluate physician office practice } \\
\text { profitability }\end{array}$ & 4 \\
\hline $\begin{array}{l}\text { Activity-based management and traditional costing in tourist enterprises (a hotel imple- } \\
\text { mentation model) }\end{array}$ & 2 \\
\hline $\begin{array}{l}\text { Applying activity based costing model on cost accounting of provider of universal postal } \\
\text { services in developing countries }\end{array}$ & 1 \\
\hline
\end{tabular}

Source: Author

Table 3 shows the indicator journals titles (HASSINI et al., 2012) presents in articles of the bibliographic portfolio. 
Table 3: Importance of Journals in the bibliographic portfolio

\begin{tabular}{ll}
\hline \multicolumn{1}{c}{ Journal } & Numbers of articles \\
\hline International Journal of Production Economics & 2 \\
The Journal of Academic Librarianship & 2 \\
African Journal of Business Management & 1 \\
Benchmarking: An International Journal & 1 \\
Critical Perspectives on Accounting & 1 \\
European Spine Journal & 1 \\
Health Care Management Review & 1 \\
Intensive Care Medicine & 1 \\
International Journal of Contemporary Hospitality Management & 1 \\
International Journal of Health Planning and Management & 1 \\
Journal of Business Research & 1 \\
Journal of the Operational Research Society & 1 \\
Library Trends & 1 \\
Operational Research & 1 \\
Ophthalmology & 1 \\
Radiology & 1 \\
The Service Industries Journal & 1 \\
Technovation & 1 \\
Transfusion & 1
\end{tabular}

Source: Author

In Table 3, one can find that the journals are of different areas, i.e., the $A B C$ method of cost is applied to different types of services, whether health, libraries, transportation, security, financial institutions, logistics and others.

Another indicator used was the number of articles per author in the portfolio, as shown in Figure 2. Altogether 59 authors were identified in the portfolio; none of the authors had a higher participation. The only author with two articles in the portfolio was Ellis-Newman, J.

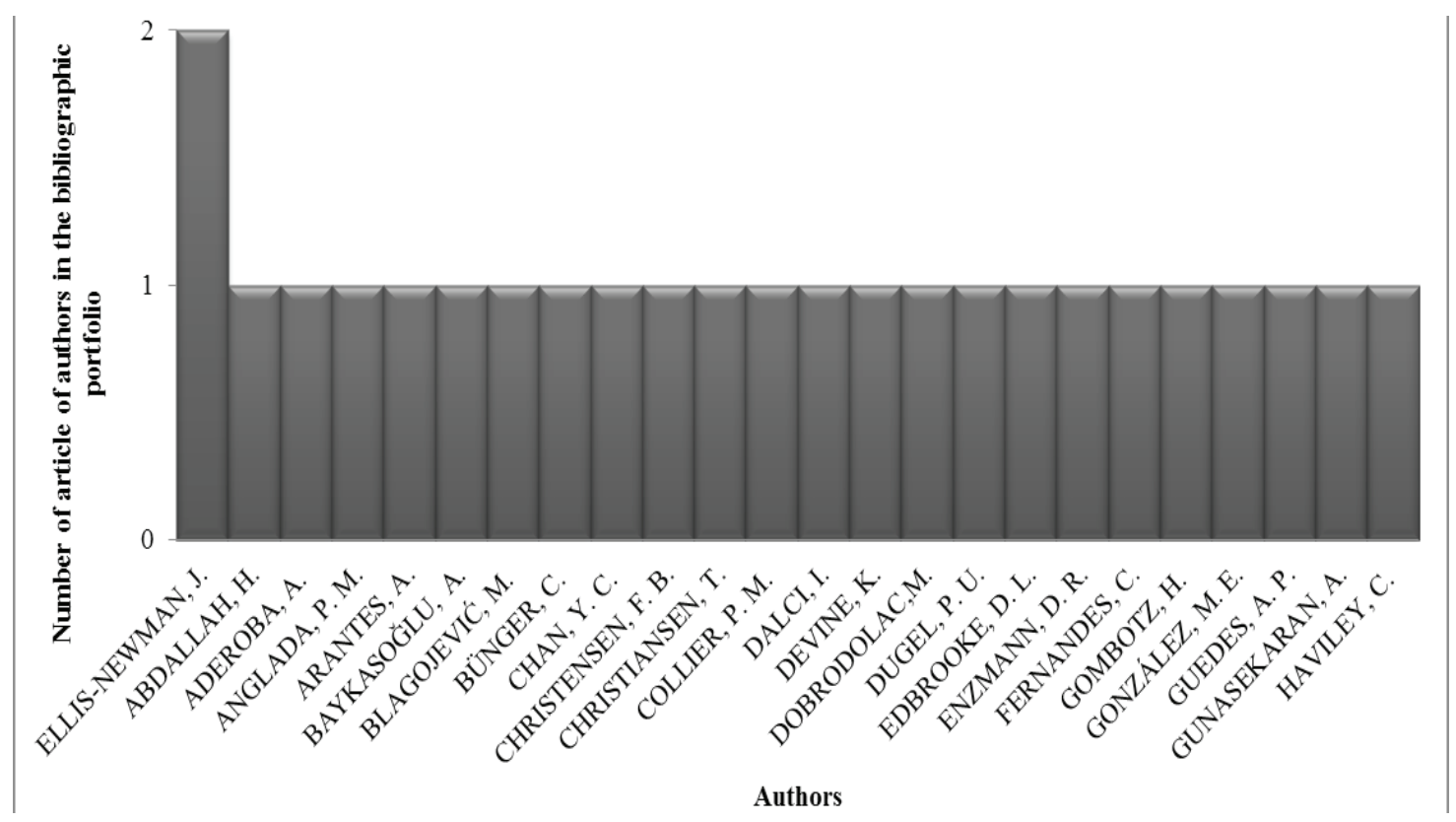

Figure 2: Relevance of the authors in the bibliographic portfolio Source: Author 
The keywords index found in the portfolio was also analyzed. The highlight is the keyword activity-based costing the search root word, followed by health services, economics, hotels. This may imply that the $A B C$ method is used in service organizations with the intention of reducing costs and improving productivity. For articles on health, there is a reservation: they focus their application of the $A B C$ method in restricted areas or department of a health organization.

\subsection{Bibliometric analysis of the portfolio references}

This subsection deals with the bibliometric analysis of the articles portfolio references. In total 305 references from 21 articles were recorded, pointing out that this result considers, only journal articles. It was found that 149 titles of journals or scientific journals were cited. Regarding the most relevant journals in the portfolio references, Journal of Cost Management and International Journal of Production Economics. Figure 3 illustrates the journals that had four or more articles in the portfolio reference.

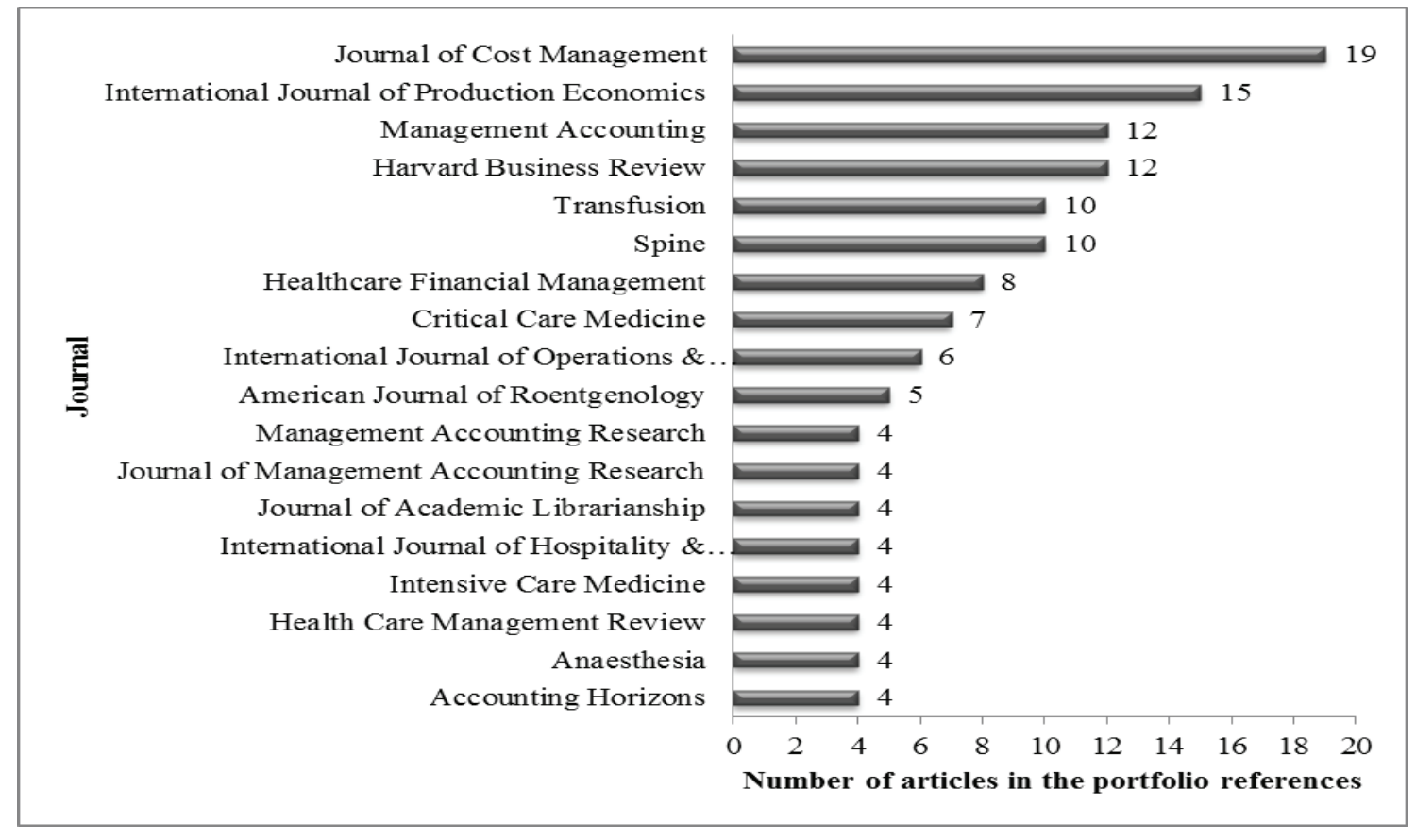

Figure 3: Journals relevance in the portfolio of articles Source: Author

The next indicator analyzed was the most cited articles (Figure 4) in the portfolio references, for such the number of times it was cited was counted. 


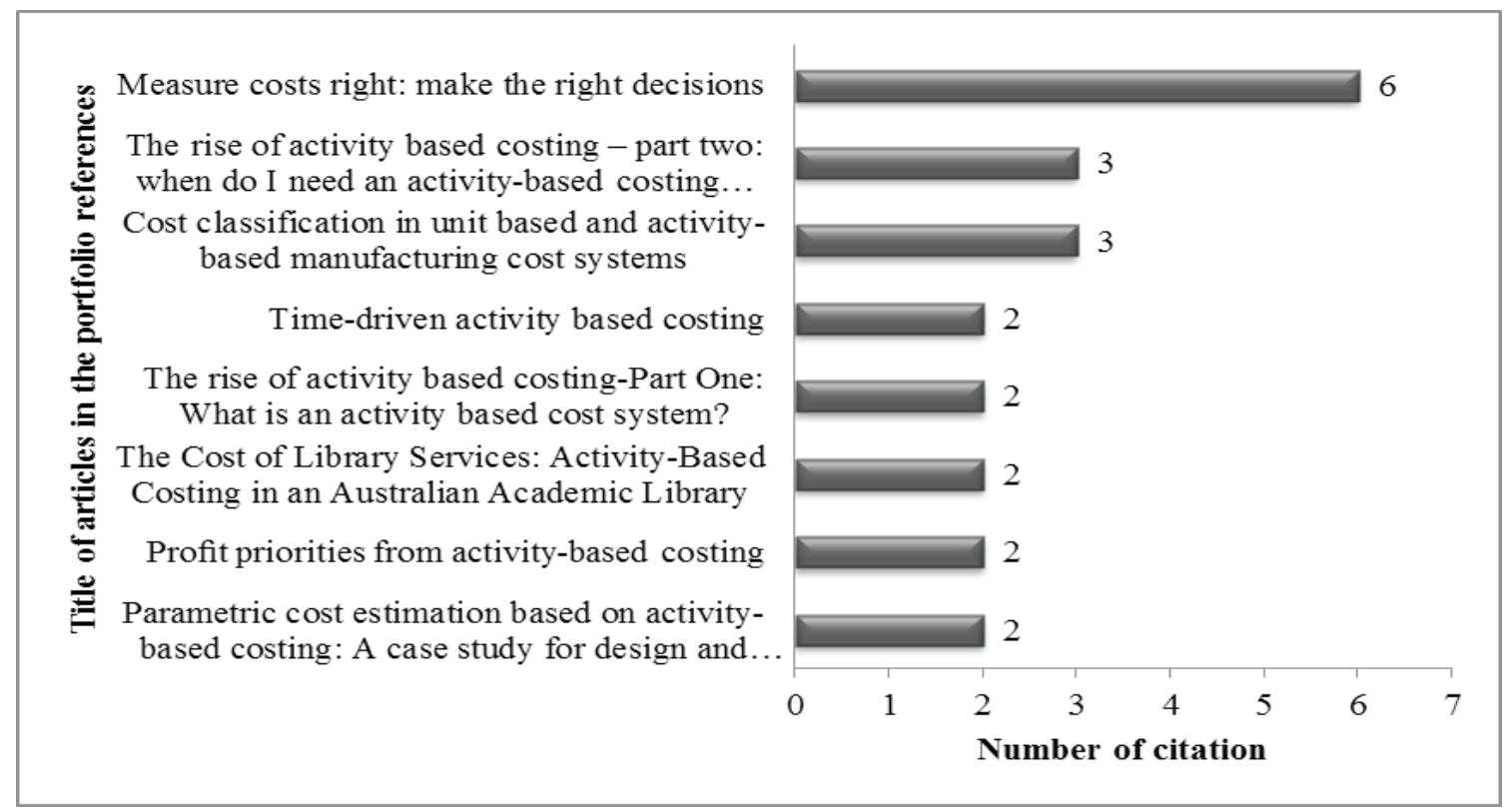

Figure 4: Most cited articles in the portfolio references Source: Author

By means of Figure 4, it can be seen that the most cited article in the portfolio references was: "Measure costs right: make the right decisions" written by Robin Cooper and Robert S. Kaplan published in Harvard Business Review in 1988. And with three citations, the articles by Robin Cooper are shown: "The rise of activity based costing - part two: when do I need an activity-based costing system" published in the Journal of Cost Management in 1988 and, "Cost classification in unit-based and activity-based manufacturing cost systems", also published in the Journal of cost Management in 1990.

Finally, the most cited author was investigated in the portfolio references. The highlighted authors are shown in Figure 5.

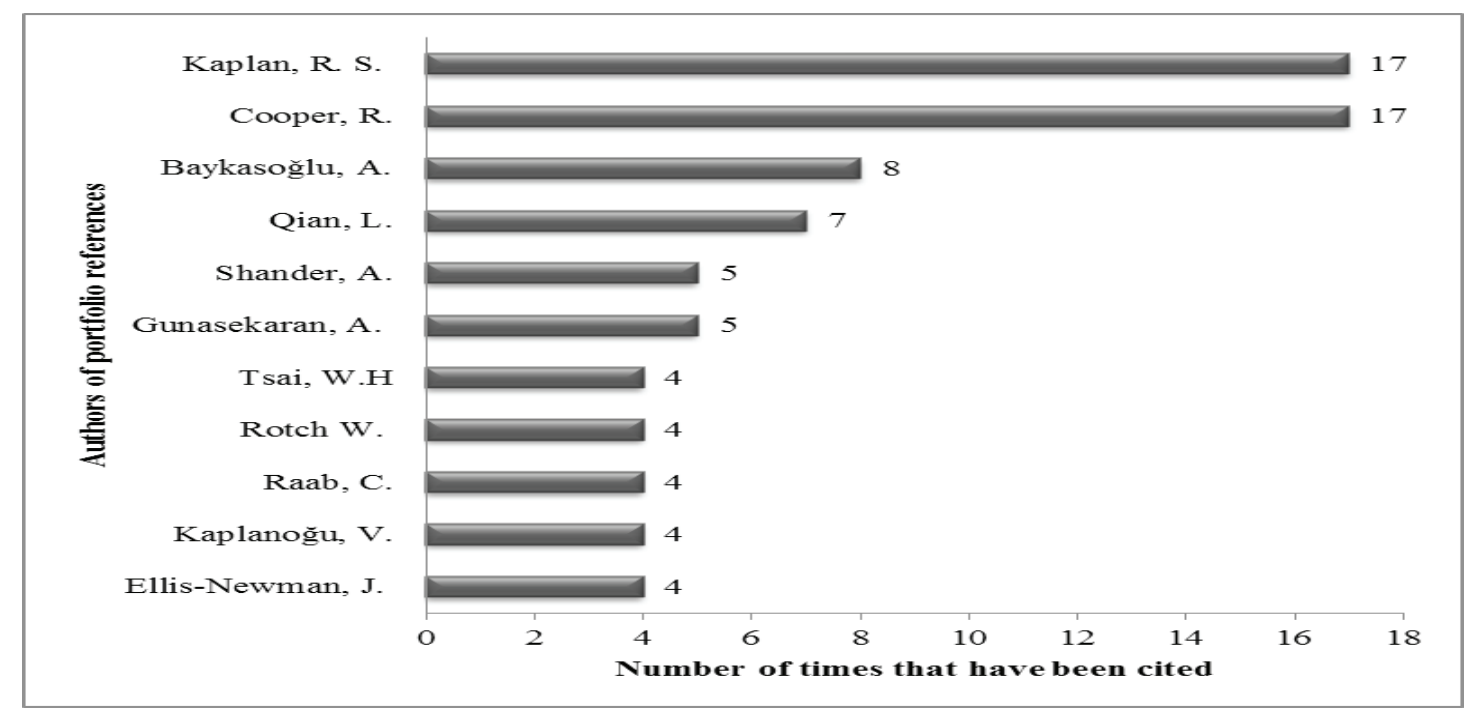

Figure 5: Most cited authors in the portfolio references Source: Author 
Therefore, this section held bibliometric analysis of the articles portfolio references built on the application of the $A B C$ method of costs in service.

\subsection{Analysis: portfolio versus portfolio references}

Having the portfolio built with 21 representative articles on the subject using the $A B C$ method in services, it was identified: the most prominent journals, titles of highlighted articles; authors who have excelled. Figure 6 shows the most prominent journals in portfolio and in its references.

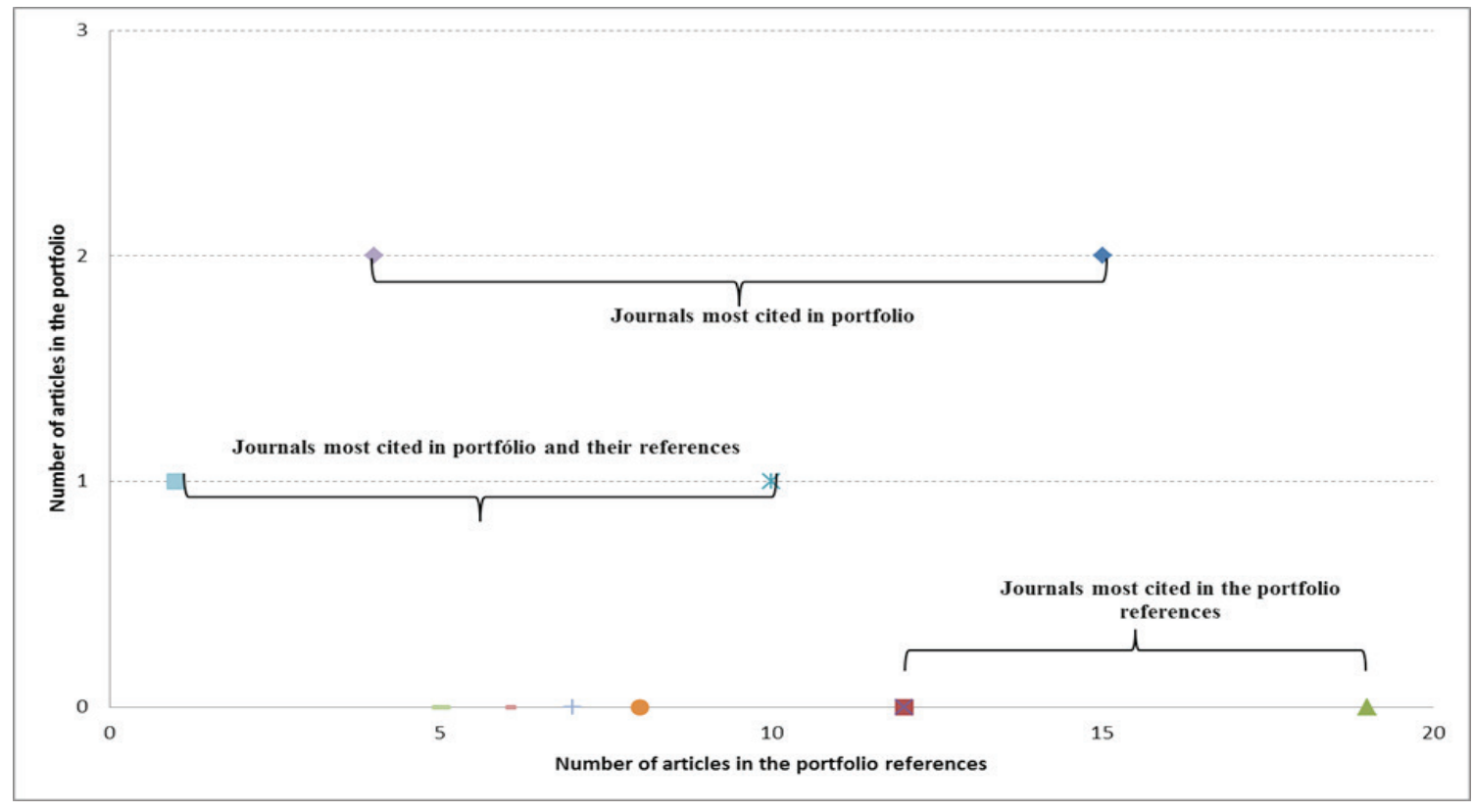

Figure 6: Most prominent journals in articles portfolio and their references Source: Author

The most cited article in the portfolio references was the Journal of Cost Management (cited 19 times in portfolio references), but no article was accounted for in the portfolio itself with this journal. This might be due to the fact that the research topic is very specific in application in services and thus causing many articles, for example, applied in industry have been left out. The second prominent journal in the portfolio as well as in its references was the International Journal of Production Economics (cited 15 times in references, and two in the portfolio). Another prominent journal in the portfolio was Journal of Academic Librarianship presenting two citations in the portfolio and only four in its references.

The following analysis refers to the authors featured in the portfolio and its references (Figure 7). The most cited author in the literature is Chan, Yee-Ching Lilian with article "Improving hospital cost accounting with activity-based costing", published in Health Care Management Review in 1993. This article was checked in Google Scholar and had 119 citations on 13/03/2012, and this number tends to increase every day that it is checked due the fact, that this or any other article is being cited in research and studies. References in the article portfolio have been cited 2 times. The second most cited paper in the literature ( 75 citations in Google Scholar and not once in the portfolio references) and present the articles portfolio is "A new method of accurately Identifying costs of individual Patients in intensive care: the initial results" of Edbrooke, D. L.; Stevens, V. G., Hibbert, C. L., published in Intensive Care Medicine in 1997. 


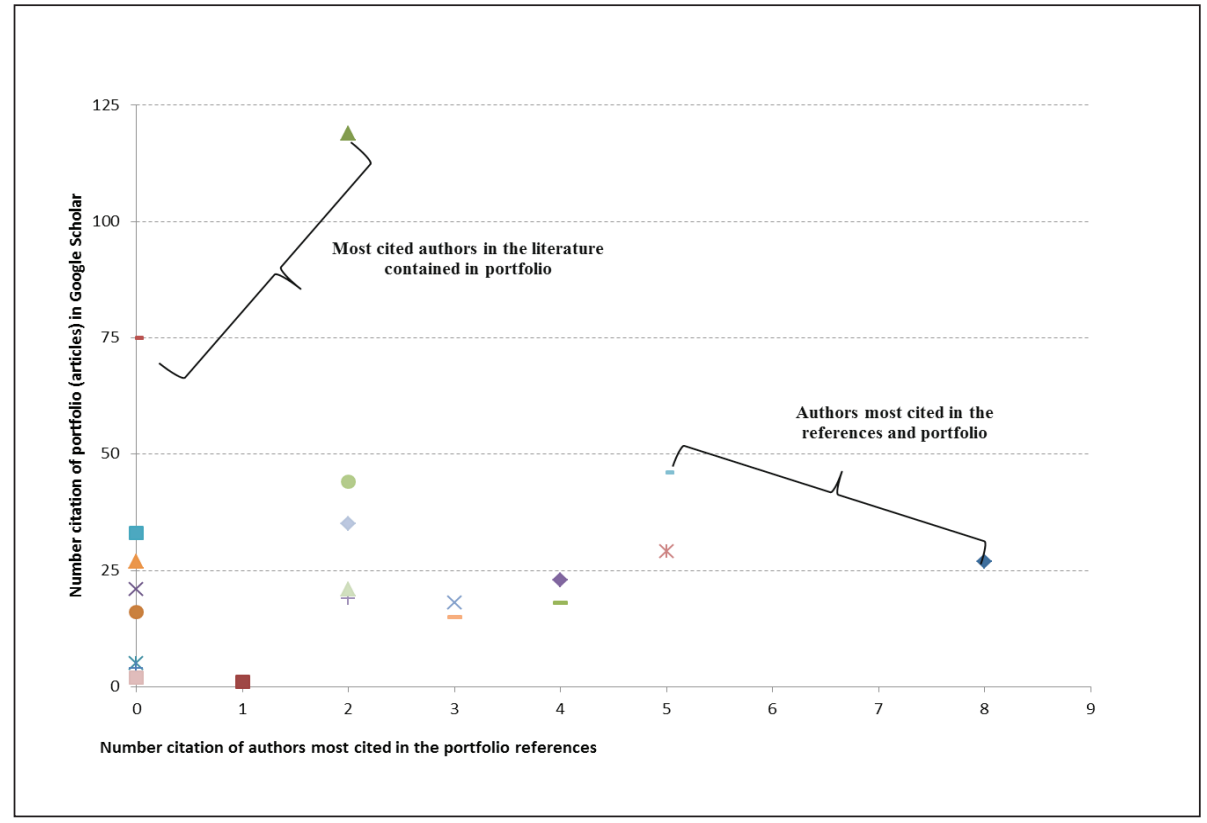

Figure 7: Authors and most outstanding title in articles portfolio of and its references Source: Author

Also in Figure 7, the most cited authors in the references were Baykasoğlu, A. and Gunasekaran, A., with 8 and 5 citations respectively. It is important to note that the citations of these authors do not relate to those contained in the portfolio, but to other works by them. The next and final analysis relates to the most outstanding items in the portfolio and its references, as shown in Figure 8.

The articles present in the portfolio and the most cited in the references are: Improving hospital cost accounting with activity-based costing (Chan, Yee-Ching Lilian); Logistic costs case study - an ABC approach (Themido, I., Arantes, A., Fernandes C., Guedes, A.P.); and Application of activity-based costing ( $A B C$ ) is a Peruvian NGO healthcare provider (Waters, H., Abdallah, H.; Santillán, D.), each with two citations.

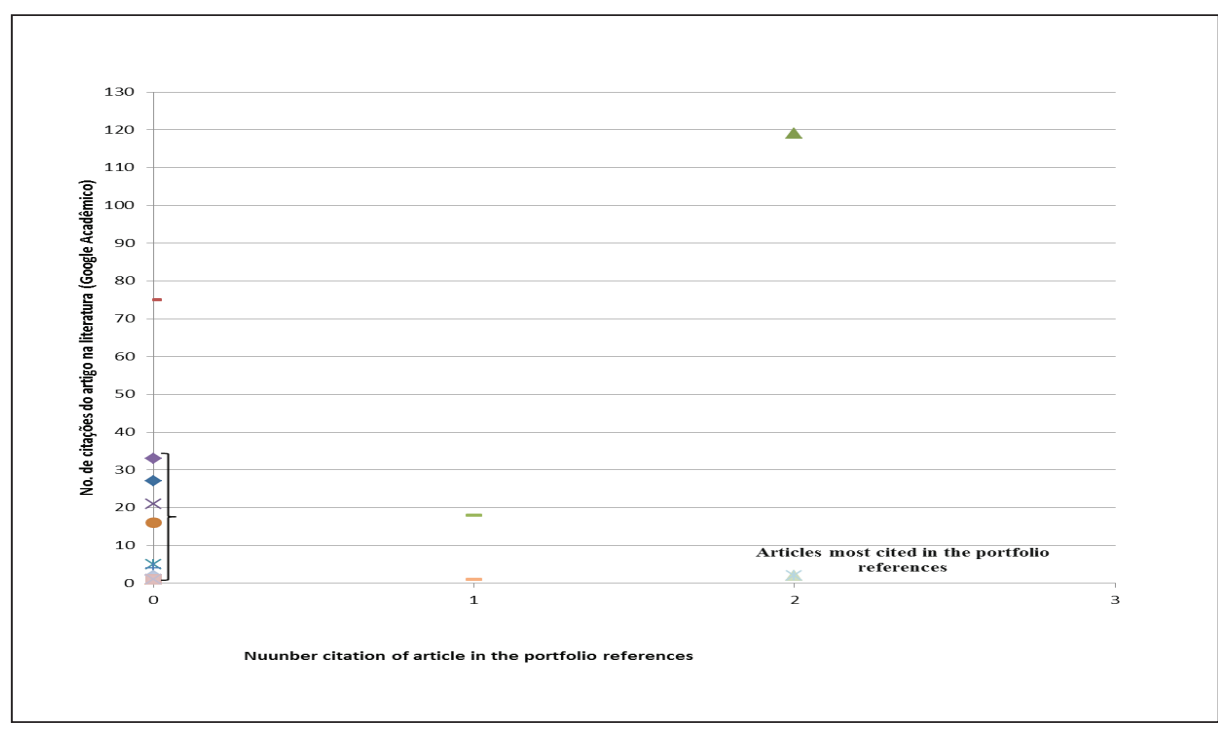

Figure 8: Most cited articles in the references and that are in the portfolio Source: Author 
Therefore, with this research it was possible to the researcher knowledge needed to start a study on the subject application of the $A B C$ method in services and also classify the types of services where they were applied i.e.: hotels; hospitals; libraries; logistics services; job shop; postal services; transportation company; police services; financial services.

In general, the characteristics of the built portfolio were:

- The majority (8 articles) of the applications of the $A B C$ method is in organizations that provide health services.

- The $A B C$ method is used in its traditional or adapted form, sometimes it is integrated into some kind of tool such as QFD and AHP.

- Most of these researches use the method to identify activities that add value and those that cause injury, in order to improve their productivity and competitiveness.

Therefore, using the $A B C$ method of cost requires a detailed study of organizations so that they can conduct an analysis to identify activities, which consume resources. An organization wishing to implement the $A B C$ method should provide sufficient resources, but also those involved in the project should carefully observe which the cost drivers are to be used. If the organization does not provide the necessary resources, the results are disastrous. For the implementation of $A B C$ to be successful, top management commitment will be needed, so that all objectives are in accordance with: strategy, quality and performance assessment, awareness of time that is required for this implementation and experience in media.

\section{CONCLUSIONS}

Organizations need constant; they are prepared to continue competing, which shows the search for alternatives for its stay in the market. Became common goal in today's business environment, improved efficiency and restructure the organization, returning it efficacy. In this context, information about the costs have become increasingly important to support and justify the process of decision-making. Therefore, $A B C$ is an information system that maintains and processes data on a firm's and products/services. It identifies the activities performed, traces costs to these activities, and then uses various cost drivers to trace the cost of activities to the final products (UDPA, 1996) or services.

This article aims to build an article portfolio about the application of the $A B C$ method in services to contribute to research on this subject. For this purpose, a three-stage procedure was performed, Planning, Implementation and Synthesis for the preparation of this portfolio. Searches carried form via journal portal Capes (in the databases ISI Web of Knowledge and Scopus), comprising the period $1990-2011$.

The formation of the bibliographic portfolio on the $A B C$ method in service firms resulted in the identification of 21 articles presented in Table 1 . A bibliometric analysis of the portfolio and its references was subsequently held. Finally a general analysis of what is each of these articles. And, by analyzing the content of each article it was possible to classify in what types of service they were applied. The majority ( 8 articles) of the applications of the $A B C$ method is in organizations that provide health services.

The advantage of this proposed methodology type in this article is that it can be used to structure any research topic in several areas. A bibliometric analysis provides a guide to researchers, because through it, for example, one can find out which journals or periodicals that publish 
on the topic you want to work, recognized authors and scientifically recognized titles.

Some limitations in the research can be highlighted: (i) only articles published in international journals were considered, (ii) research sources such as books, dissertations, theses, proceedings of conferences, events were excluded, (iii) the time period considered for the search was 1990-2011, (iv) only two databases were considered, and (v) only databases freely accessible via the portal Capes were considered.

This work, besides contributes to fostering discussions in academic science, also contributes to the business environment. For the survival of small organizations depends on their ability to generate profits. However, the generation of profits does not occur randomly, it requires careful planning, several management analyzes for decision-making. As a proposal for future studies can be highlighted as follows: use a larger number of databases; extend the time interval; informetrics and make a scientometric study on the topic.

Therefore, it is important to note that a well-structured costing method according to the needs of the organization supports consistent decision-making and is an efficient management tool. An organized cost analyzes and control system, appropriate to the aims of the organization, outlines what is happening, how best to allocate resources and therefore optimize the results.

\section{REFERENCES}

ADEROBA, A. A generalised cost-estimation model for job shops. International Journal of Production Economics, v. 53, n. 3, p. 257-263, 1997.

ANDERSON, S.W. Managing costs and coststructure throughout the value chain: research on strategic cost management. Working paper, University of Melbourne, Department of Accounting and Business Information Systems, 2005.

BAYKASOǦLU, A.; KAPLANOǦLU, V. Application of activity-based costing to a land transportation company: a case study. International Journal of Production Economics, v. 116, n. 2, p. 308324, 2008.

BLAGOJEVIĆ, M. et al. Applying activity based costing model on cost accounting of provider of universal postal services in developing countries. African Journal of Business Management, v. 4, n. 8, p. 1605-1613, 2010.

BORTOLUZZI, S.C. et al. Avaliação de desempenho em redes de pequenas e médias empresas: estado da arte para as delimitações postas pelo pesquisador. Revista Eletrônica Estratégia \& Negócios, v. 4, n. 2, p. 202-222, 2011.
BÜYÜKÖZKAN, G.; ÇIFÇI, G. A combined fuzzy AHP and fuzzy TOPSIS based strategic analysis of electronic service quality in healthcare industry. Expert Systems with Applications, v. 39, n. 8, p. 2341-2354, 2012.

BÜYÜKÖZKAN, G.; ÇIFÇI, G.; GÜLERYÜZ S. Strategic analysis of healthcare service quality using fuzzy AHP methodology. Expert Systems with Applications, v. 38, n. 8, p. 9407-9424, 2012.

CALABRESE, A. Service productivity and service quality: A necessary trade-off? International Journal of Production Economics, v. 135, n. 2, p. 800-812, 2012.

CHAN, Y.C. Improving hospital cost accounting with activity-based costing. Health Care Management Review, v. 18, n. 1, p. 71-77, 1993.

COLLIER, P.M. Costing police services: the politicization of accounting. Critical Perspectives on Accounting, v. 17, n. 1, p. 5786, 2006.

COTTON, W.D.J.; JACKMAN, S.M.; BROWN, R.A. Note on a New Zealand replication of the Innes et al. UK activity-based costing survey. Management Accounting Research, v. 14, n. 1, p. 67-72, 2003. 
CROSSAN, M.M.; APAYDIN, M. A multidimensional framework of organizational innovation: a systematic review of the literature. Journal of Management Studies, v. 47, n. 6, p. 1154-1191, 2010.

DALCI, I.; TANIS, V.; KOSAN, L. Customer profitability analysis with time-driven activitybased costing: A case study in a hotel. International Journal of Contemporary Hospitality Management, v. 22, n. 5, p. 609637, 2010.

DEVINE, K.; O'CLOCK, P.; LYONS, D. Healthcare financial management in a changing environment. Journal of Business Research, $v$. 48, n. 3, p. 183-191, 2000.

DORBAN, M.; VANDEVENNE, A.F. Bibliometric analysis of bibliographic behaviours in economic sciences. Scientometrics, v. 25, n. 1, p. 149-165, 1992.

DUGEL, P.U.; BIANCHINI, K. Development of an activity-based costing model to Evaluate physician office practice profitability. Ophthalmology, v. 118, n. 1, p. 203-231, 2011.

DUH, Rong-Ruey et al. The design and implementation of activity-based costing: a case study of a Taiwanese textile company. International Journal of Accounting and Information Management, v. 17, n. 1, p. 2752, 2009.

EDBROOKE, D.L.; STEVENS, V.G.; HIBBERT, C.L. $A$ new method of accurately identifying costs of individual patients in intensive care: the initial results. Intensive Care Medicine, v. 23, n. 6, p. 645-650, 1997.

ELLIS-NEWMAN, J. Activity-based costing in user services of an academic library. Library Trends, v. 51, n. 3, p. 333-348, 2003.

ELLIS-NEWMAN, J.; ROBINSON, P. The cost of library services: Activity-based costing in an Australian academic library. Journal of Academic Librarianship, v. 24, n. 5, p. 373-379, 1998.
ENSSLIN, L. et al. ProKnow-C, Knowledge Development Process - Constructivist. Processo Técnico com patente de registro pendente junto ao INPI, 2010, Brazil.

ENZMANN, D.R. et al. Providingprofessional mammography services: financial analysis. Radiology, v. 219, n. 2, p. 467-473, 2001.

FØRSUND, F.R.; SARAFOGLOU, N. The tale of two research communities: The diffusion of research on productive efficiency. International Journal of Production Economics, v. 98, n. 1, p. 17-40, 2005.

GONZÁLEZ M.E. et al. Building an activitybased costing hospital model using quality function deployment and benchmarking. Benchmarking, v. 12, n. 4, p. 310-329, 2005.

GRISSEMANN, U.S.; STOKBURGER-SAUER; N.E. Customer co-creation of travel services: the role of company support and customer satisfaction with the co-creation performance. Tourism Management, v. 33 , n. 6, p. 14831492, 2012.

GUMPENBERGER, C.; WIELAND M.; GORRAIZ, $J$. Bibliometric practices and activities at the University of Vienna. Library Management, $v$. 33, n. 3, p. 174-183, 2012.

GUNASEKARAN, A.; MARRI, H.B.; GRIEVE, J.R. Justification and implementation of activity based costing in small and mediumsized enterprises. Logistics Information Management, v. 12, n. 5, p. 386-394, 1999.

GUNASEKARAN, A.; SARHADI, M. Implementation of activity-based costing in manufacturing. International Journal of Production Economics, v. 56-57, p. 231-242, 1998.

GUNASEKARAN, A.; SPALANZANI, A. Sustainability of manufacturing and services: Investigations for research and applications. International Journal of Production Economics, v. 140, n. 1, p. 35-47, 2012. 
HASSINI, E.; SURTI, C.; SEARCY, C. A literature review and a case study of sustainable supply chains with a focus on metrics. International Journal of Production Economics, v. 140, n. 1, p. 69-82, 2012.

HUSSAIN, M.; GUANASEKARAN A. Activitybased cost management in financial services industry. Managing Service Quality, v. 11, n. 3, p. 213-223, 2001.

HUSSAIN, M.M.; GUNASEKARAN, A.; LAITINEN, E.K. Management accounting systems in Finnish service firms. Technovation, v. 18, n. 1, p. 57-67, 1998.

INNES, J.; FALCONER, M. The application of activity-based costing in the United Kingdom's largest financial institutions. Service Industries Journal, v. 17, n. 1, p. 190-203, 1997.

ITTNER, C.D. Activity-based Costing concepts for quality improvement. European Management Journal, v. 17, n. 5, p. 492-500, 1999.

JÄNKÄLÄ, S.; SILVOLA, H. Lagging effects of the use of activity-based costing on the financial performance of small firms. Journal of Small Business Management, v. 50, n. 3, p. 498-523, 2012.

KALLUNKI, J.P.; SILVOLA, H. The effect of organizational life cycle stage on the use of activity-based costing. Management Accounting Research, v. 19, n. 1, p. 62-79, 2008.

KELLERMANNS, F.W.; ISLAM, M. US and German activity-based costing: a critical comparison and system acceptability propositions. Benchmarking An International Journal, v. 11, n. 1, p. 31-51, 2004.

LEBAS, M. Which ABC? accounting based on causality rather than Activity-Based Costing. European Management Journal, v. 17, n. 5, p. 501-511, 1999.

LINS, L.S.; SILVA, R.N.S. Gestão empresarial com ênfase em custos: uma abordagem prática. São Paulo: Pioneira Thomson Learning, 2005.
LUTILSKY, I.D.; DRAGIJA, M. Activity based costing as a means to full costing: possibilities and constraints for European universities. Management (Croatia), v. 17, n. 1, p. 33-57, 2012.

MACIAS-CHAPULA, C.A. O papel da informetria e da cienciometria e sua perspectiva nacional e internacional. Ciência da Informação, v. 27, n. 2, p. 134-140, 1998.

MUKHERJEE, B. Scholarly research in LIS open access electronic journals: a bibliometric study. Scientometrics, v. 80, n. 1, p. 169-196, 2009.

NARAYANAN, V.G.; SARKAR, R.G. The impact of activity-based costing on managerial decisions at Insteel Industries: a field study. Journal of Economics \& Management Strategy, v. 11, n. 2, p. 257-288, 2002.

NIRAJ, R.; GUPTA, M.; NARASIMHAN, C. Customer profitability in a supply chain. Journal of Marketing, v. 65, n. 3, p. 1-16, 2001.

PERNOT, E.; ROODHOOFT, F.; VAN DEN ABBEELE, A. Time-driven activity-based costing for inter-library services: a case study in a university. Journal of Academic Librarianship, v. 33, n. 5, p. 551-560, 2007.

SCHULZE, M.; SEURING, S.; EWERING, C. Applying activity-based costing in a supply chain environment. International Journal of Production Economics, v. 135, p. 716-725, 2012.

SHANDER A. et al. Activity-based costs of blood transfusions in surgical patients at four hospitals. Transfusion, v. 50, n. 4, p. 753-765, 2010.

SOEGAARD, R. et al. Costs and effects in lumbar spinal fusion. A follow-up study in 136 consecutive patients with chronic low back pain. European Spine Journal, v. 16, n. 5, p. 657-668.

SUSSKIND, A.M. Guest service management and processes in restaurants: what we have 
learned in fifty years. Cornell Hospitality Quarterly, v. 51, n. 4, p. 479-482, 2010.

TAN, K.C.; GOUDARZLOU, A.; CHAKRABARTY, A. A bibliometric analysis of service research from Asia. Managing Service Quality, v. 20, n. 1, p. 89-101, 2010.

TASCA, J.E. et al. An approach for selecting a theoretical framework for the evaluation of training programs. Journal of European Industrial Training, v. 34 , n. 7, p. 631-655, 2010.

THEMIDO I. et al. Logistic costs case study an $A B C$ approach. Journal of the Operational Research Society, v. 51, n. 10, p. 1148-1157, 2000.

TSAI, H-H. Research trends analysis by comparing data mining and customer relationship management through bibliometric methodology. Scientometrics, v. 87, p. $425-$ 450, 2011.

TSAY, Ming-yueh., SHU, Zhu-yee. Journal bibliometric analysis: a case study on the Journal of Documentation. Journal of Documentation, v. 67, n. 5, p. 806-822, 2011.

UDPA, S. Activity-based costing hospital. Health Care Management Review, n. 21, v. 3, 1996.

VAN RAAN, A.F.J. Properties of journal impact in relation to bibliometric research group performance indicators. Scientometrics, v. 92, n. 2, p. 457-469, 2012.

VAZAKIDIS, A.; KARAGIANNIS, I. Activity-based management and traditional costing in tourist enterprises (a hotel implementation model). Operational Research, v. 11, n. 2, p. 123-147, 2011.

WATERS, H.; ABDALLAH, H.; SANTILLÁN, D. Application of activity-based costing ( $A B C$ ) for a Peruvian NGO healthcare provider. International Journal of Health Planning and Management, v. 16, n.1, p. 3-18, 2001. 